\title{
BLENDING PEDAGOGY AND DIGITAL TECHNOLOGY TO TRANSFORM EDUCATIONAL ENVIRONMENT
}

Dr. Elena A. Makarova, Taganrog Institute of Management and Economics, Russian Federation E-mail: helen_makarova@mail.ru

Dr. Elena L. Makarova, Southern Federal University, Russian Federation E-mail: elmakarova@sfedu.ru

\section{A R T I C L E I N F O}

Original Research

Received: March, 20.2018.

Revised: April, 27.2018.

Accepted: May, 03.2018.

doi:10.5937/ijcrsee $1802057 \mathrm{M}$

UDK

371.12:004

316.774:37

Keywords:

digital education,

educational environment

competence-oriented approach,

digital education technology,

tutor's technology.

\begin{abstract}
A B S T R A C T
This article shows efficacy of competences-oriented education model, representing effectiveness of pedagogy technology and digital tools blending in transforming education while using tutor's support. In correspondence to contemporary requirements and education system special features, connection between digital education tools and tutor technology contributing to students' key competences development is determined. The paper contributes to the field by summarizing some theoretical issues and offering implementation suggestions for effectively integrating digital technologies into teaching and learning. The use of digital technologies in educational activities opens up new opportunities, adequate methods for dissemination and management of digital information, development of necessary competencies on the basis of digital literacy, ensuring equitable access for all who wish to obtain necessary knowledge and decision-making skills, ensuring demand for school graduates in the world labor market in situation of digital economy. Innovative technologies become a problem adding difficulties to students' burden. Tutor becomes an intermediary between students and digital technologies to promote students' active learning practices; there are not so many students who can appreciate digital learning practices and get the most of it. The role of tutoring in digital literacy promotion is hard to overestimate. Tutor support is a pedagogical activity in individualization of education aimed at identifying and developing students' educational motives and interests. To form students' key competencies in education system, it is necessary to supplement traditional education with tools of digital educational technologies, new trends in pedagogies such as tutoring, which is becoming an integral part of modern learning process.
\end{abstract}

(C) 2018 IJCRSEE. All rights reserved.

\section{INTRODUCTION}

"We... intend to multiply the output of experts in the field of digital economy, and, in fact, we have to solve a broader task, the task at the national level, to achieve universal digital literacy. To do this, it is necessary to seriously improve the education system at all levels: from elementary school to high-school

Corresponding Author

Dr. Elena A. Makarova, Taganrog Institute of

Management and Economics, Russian Federation

E-mail: helen_makarova@mail.ru

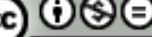

This work is licensed under a Creative Commons Attribution - NonCommercial - NoDerivs 4.0. The article is published with Open Access at www.ijcrsee.com education, and to arrange digital training programs for people of all ages". (V.V. Putin, 2017)

Digital technologies permeate the lives of $21^{\text {st }}$ century citizens. Educators recognize the instructional potential of these technologies and are seeking ways to effectively utilize them in support of learning. In this paper we would like to contribute to the field by summarizing some theoretical issues and offering implementation suggestions for effectively integrating digital technologies in teaching and learning. The increased ubiquity and instructional advantages of education digitalization have made teachers use it in their classroom in order to keep up with the modern trends in education without even evaluating as to how beneficial digital technologies are for their students.

"In their quest on being effective, ed- 
ucators have always experimented with the art of teaching. Teaching has evolved over centuries by adopting new approaches, methods, tools, and technologies to reach a wider audience" (Akbar, 2016). With new technologies it is very important not only to evaluate their influence on students, but also to combine these new trends with some traditional ones, methods known and being successful in education for years. Although teachers should definitely understand that education should utilize whatever science has to offer and follow suit, but in doing so they should not be carried away with all the innovations and new technologies no matter how well they are right for a particular class. Besides, new approaches in education create new challenges both to teachers and students.

Digital technologies are widely spread in educational institutions of all levels in the $21^{\text {st }}$ century. Educators recognize the instructional potential of these technologies and still are looking for their efficient use with students. In this paper we would like to contribute to the field by summarizing some theoretical issues and offering implementation suggestions for effectively integrating digital technologies into teaching and learning.

At the same time, undoubtedly, further digitization should ensure the improvement of the quality of education, since it becomes possible to substantially increase the amount of resources available for use in the educational process.

Today, the educational space is growing rapidly and expanding due to the development of the digital environment: electronic textbooks are being created, educational platforms appear and are developing, the number of open online courses is measured in thousands and the number of their consumers is measured in millions. Distance education has already become a part of our life.

The question is if teachers have enough high-quality content to fill the "digital capacities" that arise on a regular basis. Undoubtedly, in the use of digital technologies, there are great opportunities for schools, universities and additional education for children and adults. However, not all electronic resources make an impression of serious and high-quality ones.

Transformation in any field is never easy, in education especially, so we've proposed to put together pedagogical strategies and digital technology tools that can help along the way. In this paper we will briefly describe some of innovative teaching strategies used in high- school education along with problems and challenges they pose on students and teachers. Using digital technologies in education has become a response to these challenges. Modernization of education system is aimed at training an individual who has developed a high level of key competencies. The use of digital technologies in educational activities opens up new opportunities, adequate methods for the transfer, dissemination and management of digital information, the development of the necessary competencies on the basis of digital literacy, ensuring equitable access for all those who wish to obtain the necessary knowledge and decision-making skills, ensuring the demand for high-school graduates in the world labor market in situation of digital economy.

Competence-oriented education evolves at the expense of qualitative transformation not only of educational processes, but also of all aspects of teaching and learning activities, due to the opportunities offered by modern educational technologies, and take into account the following principal characteristic features:

- information exchange and functional interconnection of education tasks and goals;

- need to unify and harmonize the activities of various units while solving the majority of education tasks and goals;

- use of digital technologies in the learning process in particular and educational development in general (Makarova, Makarova, 2008).

Traditional teaching technologies also face challenges due to teaching styles changes and digital teaching resources emergence. Universities are starting to offer Internet access to students and teachers. All kinds of gadgets are allowed in a classroom: from a desktop computer to palm-size devices students can use instead of a dictionary, calculator or projector.

But there is an underside to all these technological advances and innovative technologies. Many teachers are so obsessed with new digital technologies they forget that they might become a rival to a teacher.

There is an opinion that in 5-7 years paper textbooks will disappear. They might remain in advanced schools. How exactly will the program be implemented? Will the paper textbook be digitized and placed in students' tablets? Or will fundamentally different textbooks be created? These advanced textbooks will follow students' progress and new educational material mastering. They will probably choose how fast the students should advance, assess how well the material has been learned, 
look for the forms of students' interaction in order to get them interested in quality performance. Besides, with these digital textbooks students will always be in a psychologically comfortable learning environment.

It is clear that with such a textbook, the teacher will soon become redundant and be virtually expelled from the educational process. Perhaps teachers will check if everything is okay with students, or change the textbook when it is over. If only a textbook is not programmed to track learning effectiveness!

In a nutshell, in 10 years' time the introduction of digital technologies will have a follow up, and the role of the teacher will undergo a global rethinking as students will no longer need to go to class. They will stay at home and study using their magical textbook. In a really positive scenario, a teacher-controller will remotely check whether the student has passed the material, how much time he spent on it, and what difficulties he has experienced in the process of studying. All of these might be used for improving a digital textbook quality.

There is one drawback in this futuristic scenario - students will never develop what we call the skills of the $21^{\text {st }}$ century: the ability to communicate with other people, or team work skills. For these skills development students' interaction is absolutely necessary to create an environment in which communicative competences are to be developed in addition to the active and interactive learning process.

So it all depends on how well teachers can combine innovative digital technologies with real teaching in the course of which students learn how to deal with the advantages offered by digital sources of information without causing damage to their argumentation or inquiring skills.

We live in a media-enriched world, so we have to use these unique opportunities to 'learn anytime and anywhere', but should not forget that our human "dynamics are becoming more and more at risk with the addictive dimension brought about by the ubiquitous presence of digital devices and social media in students' lives" (Pedro, de Oliveira Barbosa, Santos, 2018), the latter is usually associated with mobile learning.

Highly appreciated by both students and teachers, digital technologies are often seen as a remedy in themselves to many problems of education. But technologies themselves can become a problem, adding difficulties to students' and teachers' burden in high-school institution. Tutor support in digital education can become an intermediary between students and digital technologies and promote students' active learning practices. So the role of tutors in digital literacy promotion is hard to overestimate.

In the academic year of 2017-2018, research work on digital educational resources development, testing, use and blending it with a tutor support in education institutions continues. For more successful development and use of digital educational resources in the teaching and learning processes, the tutor needs to become acquainted with the requirements for the digital educational resources, their typology and content. Digital educational resources are digitized photos, video fragments, static and dynamic models, objects of virtual reality and interactive modeling, cartographic materials, sound recordings, symbolic objects and business graphics, text documents and other educational materials necessary for the organization of the teaching process.

In accordance with general requirements for digital educational resources, they should:

- correspond to the content of text-books and meet the requirements in normative acts of the Ministry of Education and Science of the Russian Federation;

- focus on modern forms and methods of education; provide high interactivity and multimedia characteristics;

- ensure the possibility of tier differentiation and individualization of education; take into account students' age and psychological needs and the corresponding differences in cultural experience;

- offer types of learning activities that guide students to acquire experience in solving life problems based on knowledge and skills within the subject;

- ensure the use of both independent and group work;

- contain variants of educational planning, assuming a modular structure;

- be based on reliable information and data;

- exceed the corresponding sections of the textbook by volume, without expanding the thematic sections;

- be fully reproduced on the declared technical platforms;

- provide the opportunity to use other programs in parallel with the digital educational resources;

- have a user-friendly interface.

Digital educational resources should not:

- represent additional chapters to the ex- 
isting textbook;

- duplicate the public reference, popu-

lar science, culture, information;

- based on materials that are out of date

(obsolete information and data).

The analysis of research work concerning organization of a competency-oriented educational process in the education system showed that they reflect the issues of developing a graduate's key competencies. To form trainees' key competencies in the education system, it is necessary to supplement traditional education with tools of digital educational technologies, new trends in pedagogies such as tutoring, which is becoming an integral part of modern learning process. The social component of competence is the ability to make an adequate decision in a specific situation. The cultural component of the competence includes professional ethics, business negotiations, and team work ability. Within the framework of the intercultural approach, the main task of modern education is personality and self-awareness development as a result of the acquisition of a new social and cultural experience.

Modern theories of blended learning describe definitions ranging from a mixture of digital technologies to a combination of pedagogical approaches. Oliver M. and Tigwell K. (Oliver, Tigwell, 2005) propose combination of four learning theories: constructivism, behaviorism, connectivism and cognitivism, to meet challenges and to optimize students' learning process; Graham C. (Graham, 2006) proposes media definition in terms of their role within pedagogical framework. Stacey E. and Gerbic P. (Stacey, Gerbic, 2009) describe blended learning a beneficial for students combination of 'face-to-face and online learning'. Macdonald J. (Macdonald, 2006) defines blended learning as a face-to-face and distance learning that would acquire 'Tutorial Mode' in which students receive the digitalized teaching and learning materials and electronic textbooks (on different devices) and also have a face-to-face tutorial contact with instructors, tutors and other academic staff on campus.

\section{MATERIALS AND METHODS}

Digitalization as one of the characteristics of education process openness and availability requires a revision of approaches to the organization of the educational process and its staffing. For modern education, special training of staff is needed, based on the definition of their competencies and taking into account the changing role of the teacher in the modern educational process. In the conditions of open education, the teacher not only represents the information, but also organizes the activity of the students to obtain this information. He does not only explain and present the material, but also answers the questions. He mustn't only give out prepared instruction for the task, but also provides help in discussing possible solutions with the students. The information extracted in such a joint activity turns into a personal knowledge of the learner, and the teacher who works this way becomes a tutor.

Tutor support is a pedagogical activity in the individualization of education aimed at identifying and developing students' educational motives and interests, searching educational resources for creating an individual educational program, working with the educational order of the student's family, and developing student's learning and educational reflection.

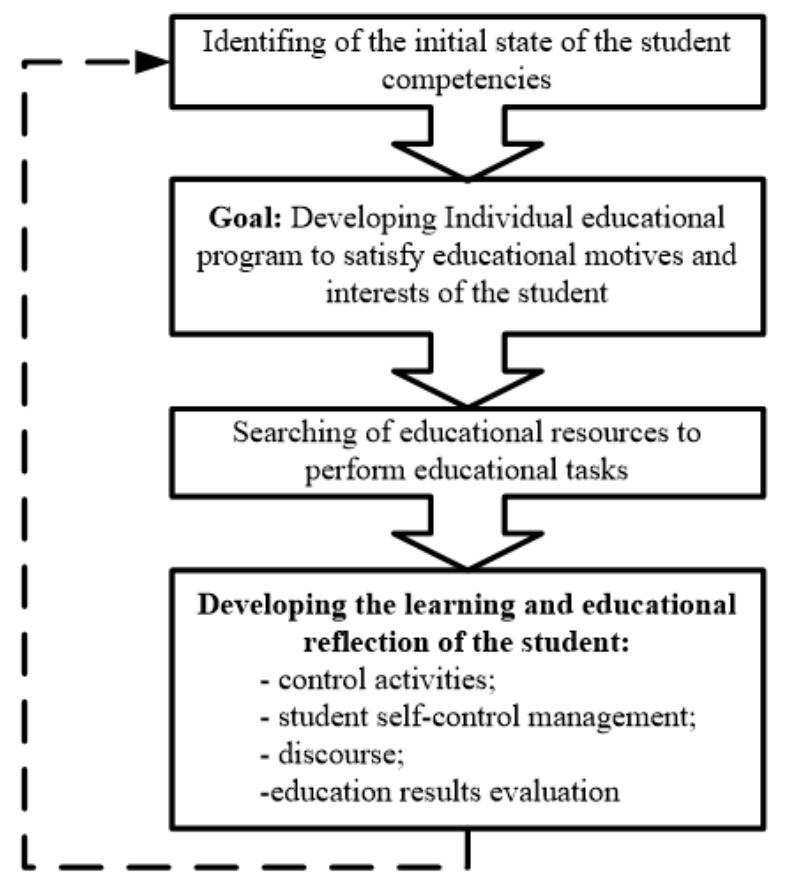

Figure 1. The activity of the teacher (tutor) during digital educational process development

The managerial activity of the teacher (tutor) can be represented in the form of blocks: identifying the initial state of knowledge, skills, goalsetting, determining the main learning strategy, setting tactical tasks, monitoring, managing the self-control of trainees, feedback, and, finally, evaluating the results of the learning process (see Fig. 1). Despite the major role of the teacher as a manager in experimental training, we consider the activ- 
ity of learners, the mobilization of intellectual, volitional efforts and emotional experiences as the basis of the digital educational process.

The tutor should be competent in the subject, it is good to know the content and structure of the course and teaching materials (not being their author), be able to assess their quality, necessarilly interact with the author of the digital course or expert (experts) in the given subject area, be able to apply pedagogical technologies in the organization learning activities. The professional activity of the tutor should:

- stimulate the development of students' independent activity taking into account the psychological and pedagogical requirements for education and training;

- analyze own activities with a view to improving it and upgrading skills;

- know the basics of social psychology, psychology of interpersonal relationships, and psychology of large and small groups;

- know the objective links of education, upbringing and development of the individual in educational processes and society;

- master modern educational technologies, methods of applying pedagogical theory in various spheres of life;

- possess the forms of business correspondence, the skills of preparing text documents;

- master the norms of official and business written speech, international and national standards of types and varieties of official documents;

- study the characteristic ways and methods of selecting linguistic material in accordance with various types of speech communication;

- be able to edit the text, focused on this or that form of speech communication;

- own the skills of independent generation of stylistically motivated text, be able to work with original literature on the specialty; have the skill of working with a reference sources.

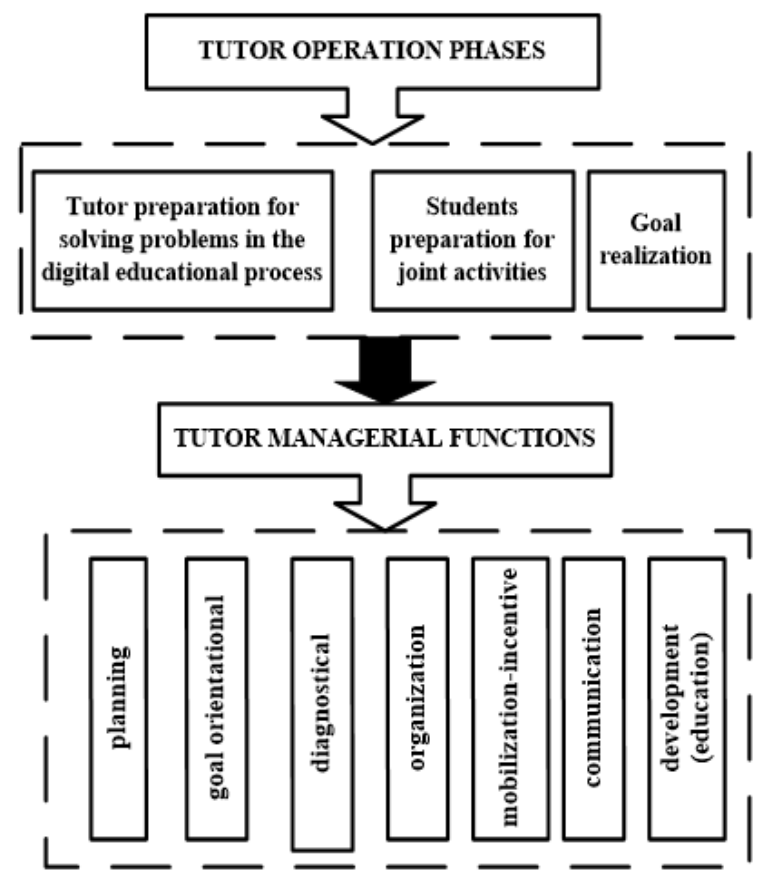

Figure 2. Tutor managerial activities

Considering tutor managerial activities (Fig. 2) primarily as an interaction, it is possible to clarify the content of communication competences, using the suggestions of specialists in the field of social interaction competences:

- to demonstrate ability to plan individual or group activities, to develop cooperation;

- to interact in various roles (limiting, supporting, developing), avoiding destructive interaction;

- to encourage trust, tolerance, empathy, respect for human rights and freedoms, reflection in cooperation with students.

At the same time, it is important that the content of the educational resources, the forms, methods and means of education at each new stage correspond to the real and potential needs of the trainees, meet their personal senses, and as a result act as a motivating factor of the learning process development. The personality of the trainee, the teacher and the learning process are combined into a complex self-organizing system that can exist and function in an interactive educational environment that promotes the development of key competences, creativity and self-learning of the student.

The ability to form key competences in the teaching process is an important task for teachers at the present stage. The analysis of available and projected key competencies allows definition of individual educational 
strategies, choice of adequate interactive educational technologies, determination of mechanisms of internal and external evaluation of a trainee.

When making a decision, the person's fundamental reaction to the emerging situation and the functioning of the brain in the decision-making mode explains the causes of the emergence of extreme situations and clearly demonstrates that the problem of using effective innovative educational technologies in the educational process is mainly of a psychological nature. Permission is largely reduced to the ability to manage emotions in order to prevent imbalances and to acquire skills to control the level of emotional load of trainees. It is about the ability to ensure the functioning of the brain in the optimal condition.

The necessity of solving this problem in connection with the increasing role of independent work of trainees in the modern educational process is explained by the following:

- educational process organization makes it possible to develop creative abilities and to join the research approach of new material studying;

- increasing the amount of information that can not be fully presented during lecture classes;

- educational process organization allows to prepare better and more qualitatively for tests and examinations.

High level of trainees' independence is provided by interactive digital educational technologies. For example, the activity of the students in the independent creation of business sessions, as one of the varieties of business games, promotes the assimilation of theoretical knowledge, the development of creative thinking, the acquisition of professional and practical skills and the preparation for stressful situations associated with decision-making while using digital educational resources (Makarova, Makarova, 2017).

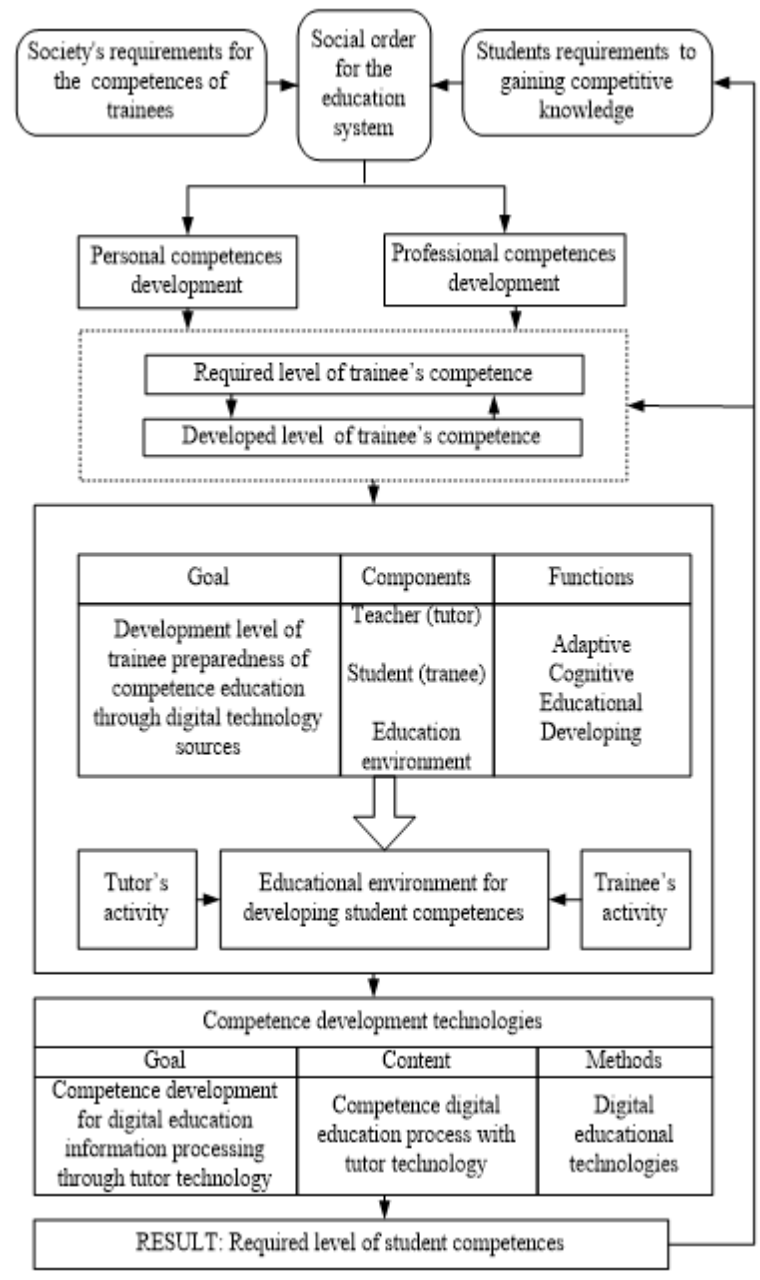

Figure 3. Competence model of digital education process on basis of tutor technology

When considering the basic principles of digital educational process development, (Fig. 3 ), the goal is trainees' independent learning, the following provisions can be proposed:

- transition to a qualitatively new level of the relationship between the teacher and the trainee, based on changing their personal positions, resulting in a partnership in educational activities;

- educational activity becomes a new type of activity for the creation of the digital educational process from the position of the manager of the process of training trainees;

- system of educational activities becomes one in which interactive digital educational technologies, productive and creative tasks play a leading role.

Thus, in organizing tutoring activities, it is necessary to take the characteristics of the learner into account, such as:

1. The need for justification

- students pay attention to the rationale 
(why they need this particular course or section).

- students will spare no time and energy to understand why and whether it is worth spending time and energy on studying the subject that is being offered to them.

\section{The need for independence}

- ability to make decisions independently, to bear responsibility for them is the main feature of the behavior and self-awareness.

- when a student enters the learning environment, a controversial situation arises: a person is sort of thrown back, into his own past, when, sitting on a school bench, he was directly or indirectly dependent on the teacher. Therefore, adult learners should be given the opportunity to choose from several alternatives and to make their own choice.

\section{Practical orientation}

The tutor has the opportunity to interact with fellow tutors, participating in permanent Internet conferences of tutors, visiting Tutor schools, various seminars, author's workshops, conferences. With the help of these specialists, students are moving away from the general, the collective to the private and education becomes individually directed. The development of tutoring should contribute to the development of teachers' staff, effectively solving the task of preparing the younger generation for life in the information society.

\section{RESULTS}

Diagnostics of the experiment on the organization of digital education process on the basis of tutor technology was carried out in the process of questioning, interviews, observations during class periods, and also on the basis of learning outcomes and testing the key competences development. To assess the effectiveness of the organization of this digital educational process, a system was used to question students in the experimental (ExGr58 students) and control (CGr - 56 students) groups. An analysis of the information obtained indicates that the majority of students showed low rates of professional competencies (elementary level - CGr-39.8, ExGr-40.9, advanced level-CGr-46.3, ExGr-31.8, high level-CGr - 13.9, ExGr-27.3)

As part of our study, a program was developed on the basis of the Lyceum No. 4 in Taganrog, which allows using interactive teaching technologies to organize a digital educational process. The purpose of this program is to develop the ability of students to independently find one or another method, depending on the nature of the material being studied and the educational task. The use of interactive educational technologies in the process of students teaching, in particular, tutoring technology, is designed for 10-11 classes and covers specialized disciplines, since vertical and horizontal communications are used, ensuring the interdisciplinarity of this system. The opportunity to work with electronic resources of the system is provided to students in a distance learning center, in computer classes, from home computers with Internet access. It should be noted that testing is possible only in specialized computer classes of the Lyceum. The educational resources of a digital educational process are used as a supplement to traditional forms and methods of teaching. They allow teachers to activate the independent work of students in the study of various disciplines, to improve the quality of their knowledge. The most important features of the described program that should be considered are openness and universality. Openness lies in the fact that it not only provides training resources to any user, but also gives teachers unlimited opportunities for the development of digital teaching materials for any school discipline. Universality is ensured by the fact that tutoring technology allows using all known methods of interactive learning. Using a universal integrated database makes it easy to expand the training program.

During the final testing, students of control (CGr) and experimental groups (ExGr) showed the following results of professional competencies development (elementary level - CGr-27, y, ExGr-10.2, advanced levelCGr-45.4, ExGr-43.4, high level-CGr - 27.3, ExGr-46.4).

Comparison of the statistical data of the ascertaining and control stages of the experiment, presented in Table 1, convincingly testifies the development of the competence of future specialists in the organization of a digital educational process using interactive technologies. 
Table 1. Comparison of the findings at the ascertaining and control stages of the experiment

\begin{tabular}{|c|c|c|c|c|}
\hline \multicolumn{5}{|c|}{ Competences } \\
\hline \multirow[b]{2}{*}{$\begin{array}{l}\text { Develop- } \\
\text { ment } \\
\text { level }(\%)\end{array}$} & \multicolumn{2}{|c|}{$\begin{array}{c}\text { Control group } \\
(\mathrm{N}=56)\end{array}$} & \multicolumn{2}{|c|}{$\begin{array}{l}\text { Experimental group } \\
(\mathrm{N}=58)\end{array}$} \\
\hline & $\begin{array}{l}\text { Begin- } \\
\text { ning of } \\
\text { experi- } \\
\text { ment }\end{array}$ & $\begin{array}{c}\text { End of } \\
\text { experi- } \\
\text { ment }\end{array}$ & $\begin{array}{c}\text { Begin- } \\
\text { ning of } \\
\text { experi- } \\
\text { ment }\end{array}$ & $\begin{array}{c}\text { End of } \\
\text { experi- } \\
\text { ment }\end{array}$ \\
\hline $\begin{array}{l}\text { elementary } \\
\text { level }\end{array}$ & 39,8 & 27,3 & 40,9 & 10,2 \\
\hline $\begin{array}{l}\text { advanced } \\
\text { level }\end{array}$ & 46,3 & 45,4 & 31,8 & 43,4 \\
\hline $\begin{array}{l}\text { highest } \\
\text { level }\end{array}$ & 13,9 & 27,3 & 27,3 & 46,4 \\
\hline
\end{tabular}

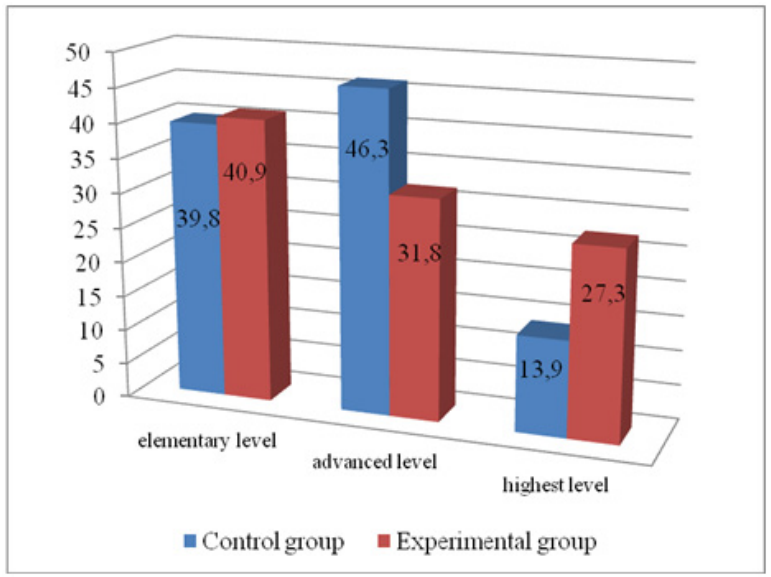

Figure 4. Comparison of the findings at the ascertaining stage of the experiment

In general, experimental groups differ significantly with higher results in all the indicators being evaluated (Fig. 4-5), which indicate the effectiveness of the pilot work and the authors' chosen strategy of organizing a digital education process on the basis of tutor technology.

\section{DISCUSSIONS}

Summarizing all of the above in this section, we can conclude that:

1. Digital educational technologies are the most promising ways to improve the competence-oriented learning process, based on the principles of problem modeling, distinguishing it from the traditional methods of the education system.

2 . The studied domestic and foreign research shows that blending of digital educational tools and innovative teaching technologies is an intensive way to increase the effectiveness of trainees' independent work, not at the expense of the volume of processed information increase, but due to the depth and speed of its processing.

3 . The activity of trainees, arising in the framework of such blending is long-time and stable, and the decisions taken independently are creative in content and emotionally colored.

\section{CONCLUSIONS}

In general, blending digital educational tools with innovative teaching technologies in teaching and learning process helps trainees improve their skills and gain experience in the following areas: identifying, selecting and solving problems; work with information - understanding the meaning of the details described in the situation; analysis and synthesis of information and arguments; work with assumptions and conclusions; evaluation of alternatives; making decisions; discussing issues and understanding other people (team work skills); consideration of problems associated with the implementation of learning management decisions; presentation of team work results; correlation of theories and concepts in the learning process and in real life activities; the coordination of conflicting goals; interactive learning; skills of conceptualizing experience; reflexive skills; skills of operational self-determination in the division of labor; self-esteem and awareness development.

\section{ACKNOWLEDGEMENTS}

The authors express their gratitude to Southern Federal University and Taganrog Institute of Management and Economics for their assistance that made the following Project possible.

\section{Conflict of interests}

The authors declare no conflict of interest.

\section{REFERENCES}

Akbar, M. (2016). Digital technology shaping teaching practices in higher education. Frontiers in ICT, 3, 1. https://doi.org/10.3389/fict.2016.00001

Graham, C. (2006). Blended learning systems: Definition, current trends, and future directions in $\mathrm{C}$. Bonk \& C. Graham (eds), Handbook of blended learning: Global perspectives, local designs, Pfeiffer Publishing, San Francisco, p.3-21.

Macdonald, J. (2006). Blended Learning and Online Tutoring: A Good Practice Guide, 
$2^{\text {nd }}$ edn. Gower. Hampshire. https://doi. org/10.1108/00197850610704598

Makarova E. A., Makarova E. L. (2017). Особенности профессионально-ориентированного обучения в компетентностном образовательном пространстве: монография, [Features professionally-oriented training in competency-based educational space: monograph]. М, ИНФРА-М, 130 р. УДК 378(075.4), ISBN 978-5-16-012617-3

Oliver, M., \& Trigwell, K. (2005). Can 'blended learning'be redeemed?. E-learning and Digital Media, 2(1), 17-26. http://journals.sagepub. com/doi/pdf/10.2304/elea.2005.2.1.17

Pedro, L. F. M. G., de Oliveira Barbosa, C. M. M., \& das Neves Santos, C. M. (2018). A critical review of mobile learning integration in formal educational contexts. International Journal of Educational Technology in Higher Education, 15(1), 10. https://doi.org/10.1186/s41239-0180091-4

Stacey, E., Gerbic, P. (2009). Introduction to blended learning practices. In E. Stacey \& P. Gerbic (eds), Effective blended learning practices: Evidence based perspectives in ICT-facilitated education, Information Science Reference, Hershey, pp.1-19 https://goo.gl/VjUMKW

Макарова, Е., \& Макарова, Е. (2015). Формирование системы профессиональных компетенций специалистов в вузе. [Development of experts' professional competences system in high school] Российский психологический журнал, 5(4), 48-55. Получено из http://rpj.ru.com/index.php/rpj/article/view/276 